\title{
HUBUNGAN PENGETAHUAN BERKENDARA SELAMAT DENGAN KECELAKAAN PENGEMUDI TRANSPORTASI RODA DUA BERBASIS ONLINE DI KOTA PEKANBARU
}

\author{
Raihanatu Binqalbi Ruzain, Yulia Herawati, Daniel Christofa \\ Universitas Islam Riau \\ raihanatu.binqolbi@psy.uir.ac.id
}

\begin{abstract}
ABSTRAK
Kecelakaan Lalu Lintas Jalan merupakan penyebab utama kematian dan cedera dan masalah kesehatan masyarakat yang meningkat secara global, mengakibatkan lebih dari 1,2 juta kematian setiap tahunnya. Lebih dari 62.000 orang tewas dalam kecelakaan lalu lintas yang melibatkan sepeda motor di 27 negara Uni Eropa antara tahun 2001 dan 2009. Kemajuan transportasi roda dua berbasis online merupakan jawaban kebutuhan transportasi masyarakat saat ini, transportasi ini memberi kemudahan berupa masayarakat dapat menggunakan transportasi dengan cepat, efisien, ekonomis dan biaya yang pasti. Tujuan penelitian ini untuk mengetahui hubungan berkendara selamat dengan kecelakaan pengemudi transportasi roda dua berbasis online. Penelitian ini bersifat kuantitatif dengan korelasi Product Moment obsevasional. Subjek penelitian ini adalah pengemudi transportasi roda dua berbasis online sejumlah 100 orang. Pengetahuan berkendara selamat sebagai variable bebas dan kecelakaan pengemudi sebagai variable terikat. Dipenelitian terdapat hubungan signifikan antara pengetahuan berkendara selamat dengan kecelakaan pengemudi transportasi roda dua berbasis online. Pengemudi disarankan untuk meningkatkan pengetahuan berkendara selamat dengan membaca, mengikuti seminar dan pelatihan .
\end{abstract}

Kata kunci: Berbasis online, berkendara selamat, , kecelakaan pengemudi

\section{PENDAHULUAN}

Kecelakaan Lalu Lintas Jalan merupakan penyebab utama kematian dan cedera dan masalah kesehatan masyarakat yang meningkat secara global, mengakibatkan lebih dari 1,2 juta kematian setiap tahunnya. (WHO, 2015). Lebih dari 62.000 orang tewas dalam kecelakaan lalu lintas yang melibatkan sepeda motor di 27 negara Uni Eropa antara tahun 2001 dan 2009 (ETSC, 2011). Kecelakaan lalu lintas jalan dianggap sebagai penyebab kematian tertinggi kedua di Iran(Montazeri, 2004). Di negara berkembang lebih dari 85\% kematian disebabkan oleh kecelakaan lalu lintas dan 90\% yang mengalami kecacatan berasal dari cedera lalu lintas (Nantulya M, 2011). Di Indonesia data dari Polri tahun 2010, kecelakaan lalu lintas yang mengakibatkan kematian 31.186 jiwa. Kecelakaan lalu lintas ini disebabkan meningkatnya jumlah kendaraan roda dua. (Manurung J R, 2008).

Mobilitas masyarakat yang tinggi membutuhkan transportasi yang membuat dirinya bisa melakukan aktifitas cepat, efisien waktu (real time), 
ekonomis dxsan biaya yang pasti (Astuti, 2011). Terobosan transportasi berbasis aplikasi online yang menggabungkan jasa transportasi konvensional dengan teknologi komunikasi di dunia transportasi, membuat masyarakat mampu memenuhi kebutuhannya. Menjalankan pekerjaan sebagai pengemudi transportasi online tentunya berbeda dengan pengemudi transportasi konvensional. Pada transportasi online pengemudi (driver) tidak hanya membawa kendaraan namun juga harus mengawasi handphone disalah satu tangannya untuk melihat rute jalan yang sudah di atur oleh GPS. Hal ini harus dilakukan oleh pengemudi di jalan raya baik dalam kondisi sepi ataupun ramai (Constance,2016).

Kasus-kasus kecelakaan pengemudi transportasi roda dua Online terjadi melibatkan kesalahan disain jalan dan faktor manusia. Faktor yang paling fatal adalah kesalahan manusia. Hal ini termasuk ketidaktahuan dan ketidakpedulian peraturan lalu lintas serta kondisi jalan, kurangnya keterampilan mengemudi, persepsi yang buruk, kegagalan untuk berespon dan menyesuaikan dengan kondisi jalan raya (EU-OSHA, 2010).

Islam juga menerangkan jika suatu urusan diserahkan bukan ahlinya berisiko seperti diterangkan berkut:

$$
\text { إذا وسد الامر إلى غير أهله فانتظر الساعة }
$$

Terjemah Arti: "Jika urusan diserahkan bukan kepada ahlinya, maka akan tunggulah terjadinya kiamat" (HR. al Bukhary)

Kecelakaan lalu lintas ini juga diakibatkan oleh faktor lain yang terkait dengan kontrol lalu lintas yang tidak memadai, kurangnya manajemen lalu lintas, dan kemacetan lalu lintas adalah faktor utama yang menyebabkan pengemudi mengemudi secara agresif disertai kemarahan. Lebih penting lagi, sebagian besar studi mengidentifikasi perilaku mengemudi dan sikap pengemudi, termasuk kecepatan yang berlebihan dan terburu-buru, untuk menjadi faktor utama penyebab kecelakaan lalu lintas. (Ismeik 2010, Abojaradeh 2012 )

Didalam Q.S Al-Anbiya ayat 37, Allah telah menjelaskan tentang perbuatan terburu-buru atau tergesa-gsa

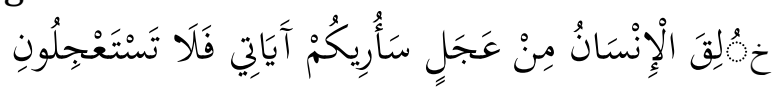

Artinya: "Manusia telah dijadikan (bertabiat) tergesa-gesa. Kelak akan Aku perlihatkan kepadamu tanda-tanda azab-Ku. Maka janganlah kamu minta kepada-Ku mendatangkannya dengan segera." (QS. Al-Anbiya': 37).

Begitu intensnya perbuatan terburu-buru atau tergesa-gesa juga dijelaskan pada Q.S Al Isra ayat 11 :<smiles>[AsH2][AsH2][AsH2]=[AsH2]</smiles>

Terjemahan artinya: "Dan manusia bersifat tergesa-gesa." (QS. Al-Isrâ’: $11)$. 
Dan juga di HR.Abu Ya'la dan Al-Baihaqi juga menjelaskan tergesa-gesanya manusia

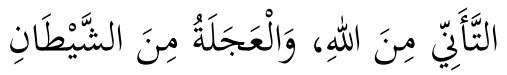

Artinya:'Tidak tergesa-gesa (ketenangan) datangnya dari Allah sedangkan tergesa-gesa datangnya dari setan.” (HR. Abu Ya'la dan Al-Baihaqi)

Perilaku berkendara selamat adalah perilaku berkendaraan roda dua dengan tata cara yang aman sesuai dengan peraturan lalu lintas. Hal ini bertujuan menghindari terjadinya kecelakaan lalu lintas dengan mementingkan dan mengutamakan keselamatan, baik bagi diri sendiri maupun bagi orang lain di dalam berkendara dijalan raya. Pekerjaan yang dilakukan pengemudi transportasi roda dua online memiliki resiko keselamatan kerja yang tidak sedikit, seperti harus memperhatikan keamanan dan kenyamanan dalam berkendara, ruang lingkup tempat kerja pengemuditransportasi roda dua online juga memiliki lingkup yang luas bahkan di tempat-tempat yang sepi yang memungkinkan besarnya terjadi kecelakaan atau tindak kriminal yang di lakukan di tempat-tempat sepi (Bagyono, 2004)

Pengetahuan mengenai pengemudi transpotasi roda dua online penting diberikan secara bertahap, agar individu dalam berkendara dengan selamat (Rachmawati , 2008).

Islam menerangkan pentingnya pengetahuan berikut ini :

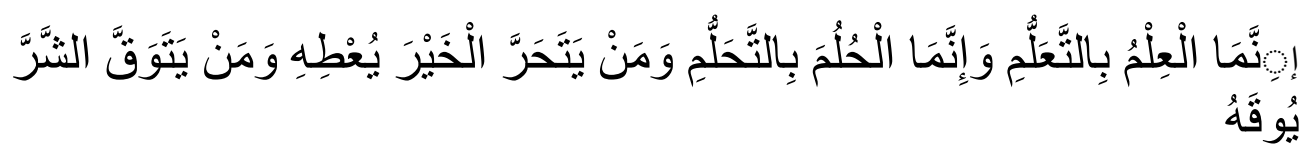

Artinya: "Sesungguhnya ilmu didapatkan dengan belajar dan sesungguhmua hilm (kesabaran dan ketenangan) didapat dengan melatihnya. Barangsiapa berusaha untuk mendapat kebaikan, maka Allah akan memberikannya. Barangsiapa yang berusaha untuk menghindari keburukan, niscaya akan terhindar darinya." (HR. Ath-Thabrani).

Didalam Q.S Al-Isra Ayat 36, Allah telah menjelaskan tentang pentingnya pengetahuan :

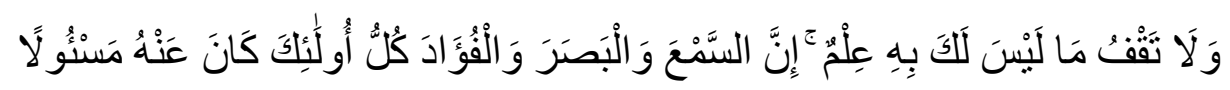

Terjemah Arti: Dan janganlah kamu mengikuti apa yang kamu tidak mempunyai pengetahuan tentangnya. Sesungguhnya pendengaran, penglihatan dan hati, semuanya itu akan diminta pertanggungan jawabnya(Surat Al-Isra Ayat 36)

Dan begitu juga di QS. An Nahl: 43 menerangkan tentang pengetahuan :

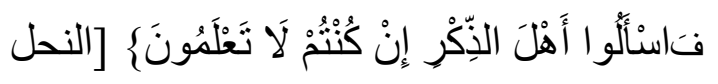


Artinya: " maka bertanyalah kepada orang yang mempunyai pengetahuan jika kamu tidak mengetahui". QS. An Nahl: 43.

Keselamatan dan kesehatan kerja pada pengemudi transportasi berbasis online menjadi tanggung jawab pengemudi dan juga perusahaan. Selain untuk memenuhi hak akan keselamatan dan kesehatan pribadi pengemudi, keselamatan dan kesehatan kerja yang dijalankan dan diberikan dengan baik juga akan memberikan dampak positif bagi perusahaan dengan mengingat bahwa keselamatan dan kesehatan kerja ini memiliki hubungan dengan peningkatan kinerja pengemudi (Slaudiya, 2018).

\section{METODOLOGI}

Penelitian ini bersifat kuantitatif dengan korelasi Product Moment obsevasional. Subjek penelitian ini adalah pengemudi transportasi roda dua berbasis online sejumlah 100 orang. Pengetahuan berkendara selamat sebagai variable bebas dan kecelakaan pengemudi sebagai variable terikat.

Pengetahuan berkendara selamat didefiniskan sebagai pengetahuan mengemudi sesuai dengan peraturan lalu lintas dengan memperhatikan keselamatan bagi pengemudi, penumpang dan penggua jalan raya lainnya. Skala pengetahuan berkendara selamat disusun berdasarkan aspek-aspek Pengetahuan Safety Riding menurut Imanuel (2016)

Kecelakaan pengemudi adalah suatu kejadian tidak terduga dan tidak dikehendaki yang menimbulkan cedera, kerusakan dan kematian. Skala kecelakaan kerja disusun dengan menggunakan teori Notoatmodjo( 2007).

Signifikansi hubungan diketahui dengan menggunakan product moment korelasi Pearson. Analisis ini untuk mengetahui hubungan pengetahuan berkendara selamat dengan kecelakaan pengemudi

\section{HASIL PENELITIAN}

Penelitian hubungan pengetahuan berkendara selamat dengan kecelakaan pengemudi transportasi roda dua berbasis online di kota Pekanbaru dilaksanakan pada tanggal 12 Oktober - 30 Oktober 2019 dengan jumlah sampel 100 orang. Penelitian dilakukan dengan menggunakan google form yang disebarkan melalui WhatsApp kepada pengemudi ojek online di kota Pekanbaru. Pengemudi diberikan sebuah link yang berisi dua skala, yaitu skala pengetahuan berkendara selamat dengan 32 aitem dan skala kecelakaan pengemudi dengan 21 aitem.

Hasil penelitian hubungan pengetahuan berkendara selamat dengan kecelakaan pengemudi transportasi roda dua berbasis online di kota Pekanbaru pada 100 pengemudi.

Data deskripsi subjek pada penelitian ini dapat dilihat dari tabel 1 sebagai berikut:

Tabel 1. Data Demografi Penelitian

\begin{tabular}{lll}
\hline Umur & Frekuensi & Persentase \\
\hline
\end{tabular}




\begin{tabular}{llll}
\hline & 17-21 Tahun & 33 & $33 \%$ \\
\cline { 2 - 4 } & 21-40 Tahun & 67 & $67 \%$ \\
\cline { 2 - 4 } Jeni Kelamin & Laki -laki & 96 & - \\
\cline { 2 - 4 } & Perempuan & 4 & $96 \%$ \\
\hline Pendidikan & SD & 22 & $4 \%$ \\
Terakhir & SMP & 11 & $22 \%$ \\
& SMA & 27 & $11 \%$ \\
& D3 & 4 & $27 \%$ \\
& S1 & 36 & $4 \%$ \\
Lama Mengemudi & $<10$ Tahun & 42 & $36 \%$ \\
& $>10$ Tahun & 58 & $42 \%$ \\
\hline Pelanggaran & Ada & 9 & $58 \%$ \\
berbahaya & Tidak Ada & 91 & $9 \%$ \\
\hline Jam kerja & $<8$ Jam & 23 & $91 \%$ \\
\hline Pelanggaran lalu & Ada Jam & 77 & $23 \%$ \\
Lintas & Tidak Ada & 48 & $77 \%$ \\
\hline
\end{tabular}

Bedasarkan hasil penelitian umur responden paling dominan adala berumur 21 hingga 40 tahun atau tergolong umur dewasa awal sebesar $67 \%$. Rentang umur demikian adalah rentang umur pekerja. Jenis kelamin yang paling dominan dalam penelitian ini adalah laki-laki yaitu 96\%. Pengumudi Ojek online pada umumnya didominasi laki-laki. Pendidikan terakhir informan penelitian ini paling dominan adalah lulusan Strata satu (S1) sebesar 36\%, dengan lama mengemudi paling banyak adalah lebih dari 10 tahun yaitu 58\%. Pelangaran berbahaya yang dilakukan oleh informan penelitian hanya $9 \%$ dengan jam kerja paling dominan adalah lebih dari 8 jam, yaitu 77\%. Sedangkan pelanggaran lalu lintas banyak dilakukan oleh informan, yaitu sebesar $52 \%$ dari 100 informan.

Berdasarkan hasil data penelitian yang diperoleh dapat diketahui deskripsi data penelitian mengenai skor minimal, skor maksimal, rata-rata, standar deviasi (SD) pada setiap skala tabel 2 berikut ini:

Tabel 2Deskripsi Data Penelitian

\begin{tabular}{lcccccccc}
\hline $\begin{array}{l}\text { Variabel } \\
\text { Penelitian }\end{array}$ & \multicolumn{3}{c}{$\begin{array}{c}\text { Skor X yang diperoleh } \\
\text { (Empirik) }\end{array}$} & \multicolumn{4}{c}{$\begin{array}{c}\text { Skor X yang dimungkinkan } \\
\text { (Empirik) }\end{array}$} \\
\hline & X max & X min & Rerata & SD & $\begin{array}{c}\text { X } \\
\text { max }\end{array}$ & X min & Rerata & SD \\
\hline $\begin{array}{l}\text { Kecelakaan } \\
\text { Kerja }\end{array}$ & 100 & 56 & 85,11 & 6,610 & 105 & 0 & 100,5 & 8,90 \\
\hline $\begin{array}{l}\text { Berkendara } \\
\text { selamat }\end{array}$ & 90 & 38 & 72,62 & 7,285 & 90 & 0 & 90 & 9.80 \\
\hline
\end{tabular}


Berdasarkan data di atas diketahui bahwa rerata emprik yang diperoleh dari data penelitian adalah 85,11 pada vaiabel kecelakaan kerja dan 72,62 pada variable berkendara selamat. Pada nilai variabel kecelakaan kerja dapat diketahui bahwa nilai maksimal variabel adalah 100 dan minimal 56. Pada variabel keselamatan berkendara nilai maksimal adalah 90 dan nilai minimal adalah 38.

Berdasarkan deskripsi data di atas dengan menggunakan rumus yang telah ditentukan maka skala dalam penelitian ini terbagi menjadi lima kategori, yaitu Sangat Baik, Baik, Cukup Baik, Tidak Baik, Sangat Tidak Baik. Kategori skor pada skala kecelakaan dilihat pada tabel 3:

Tabel 3

Kategorisasi dan Deskripsi Persentase Skala Kecelakaan

\begin{tabular}{cccc}
\hline Kategori & Skor & Frekuensi & entase \\
\hline Sangat Baik & $X \geq 95,02$ & 3 & \\
Baik & $41 \leq X<95,02$ & 24 & $+\%$ \\
Cukup Baik & $\mathbf{3 0} \leq \mathbf{X}<\mathbf{8 8 , 4 1}$ & $\mathbf{5 8}$ & $\mathbf{;} \%$ \\
Tidak Baik & $19 \leq X<81,80$ & 7 & $\%$ \\
Sangat Tidak Baik & $<75,19$ & 8 & $; \%$ \\
\hline Jumlah & $\mathbf{1 0 0}$ & $\mathbf{0 0 \%}$ \\
\hline
\end{tabular}

Dari tabel diatas dapat diketahui bahwa hasil persentase skala kecelakaan pada pengemudi ojek online pada kategori Sangat Baik sebanyak 3 pengemudi atau 3\%, kategori Baik sebanyak 24 atau 24\%, kategori Cukup Baik sebanyak 58 siswa atau 58\%, kategori Tidak Baik sebanyak 7 atau 7\%, dan kategori Sangat Tidak Baik sebanyak 8 atau 8\%. Data hasil penelitian ini menunjukan bahwa persentase skala kecelakaan pada pengemudi ojek online tergolong cukup baik dengan jumlah sebanyak 58 atau 58, 7\%.

Tabel 4

Kategorisasi dan Deskripsi Persentase Keselamatan Berkendara

\begin{tabular}{cccc}
\hline Kategori & Skor & Frekuensi & Presentase \\
\hline Sangat Baik & $\mathrm{X} \geq 83,54$ & 5 & \\
Baik & $26 \leq \mathrm{X}<83,54$ & 16 & $16 \%$ \\
Cukup Baik & $\mathbf{8 8} \leq \mathbf{X}<\mathbf{7 6 , 2 6}$ & $\mathbf{6 7}$ & $\mathbf{6 7} \%$ \\
Tidak Baik & $70 \leq \mathrm{X}<68,98$ & 3 & $3 \%$ \\
Sangat Tidak Baik & $<61,70$ & 9 & $9 \%$ \\
\hline \multicolumn{2}{c}{ Jumlah } & $\mathbf{1 0 0}$ & $\mathbf{1 0 0 , 0 0 \%}$ \\
\hline
\end{tabular}

Dari tabel diatas dapat diketahui bahwa hasil persentase skala keselamatan berkendara pada pengemudi ojek online pada kategori Sangat Baik sebanyak 5 pengemudi atau 5\%, kategori Baik sebanyak 16 atau 16\%, kategori Cukup Baik sebanyak 67 siswa atau 67\%, kategori Tidak Baik sebanyak 3 atau 3\%, dan kategori Sangat Tidak Baik sebanyak 9 atau 9\%. Data hasil penelitian ini menunjukan bahwa persentase skala kecelakaan pada pengemudi ojek online tergolong cukup baik dengan jumlah sebanyak 67 atau $67 \%$. 
Berdasarkan tabel 5 diketahui bahwa nilai sig ( 2 tailed) adalah sebesar 0.000 yang berarti $\mathrm{p}<0.05$, sehingga hipotesis yang diajukan penulis diterima karena terdapat hubungan yang signifikan antara variabel berkendara selamat dengan Kecelakaan kerja pengemudi ojek online. Jika melihat seberapa besar hubungan antar variabel maka dapat dibandingkan pada tabel berikut ini:

\section{Tabel 5 Uji HipotesisCorrelations}

\begin{tabular}{|c|c|c|c|c|}
\hline & & & $\mathrm{Y}$ & $\mathrm{X}$ \\
\hline \multirow[t]{6}{*}{$\begin{array}{l}\text { Spearman's } \\
\text { rho }\end{array}$} & \multirow[t]{3}{*}{$\mathrm{Y}$} & $\begin{array}{l}\text { Correlation } \\
\text { Coefficient } \\
\end{array}$ & 1,000 & , 428 \\
\hline & & Sig. (2-tailed) & . &, 000 \\
\hline & & $\mathrm{N}$ & 100 & 100 \\
\hline & \multirow[t]{3}{*}{$\mathrm{X}$} & $\begin{array}{l}\text { Correlation } \\
\text { Coefficient }\end{array}$ &, $428^{* *}$ & 1,000 \\
\hline & & Sig. (2-tailed) &, 000 & \\
\hline & & $\mathrm{N}$ & 100 & 100 \\
\hline
\end{tabular}

**. Correlation is significant at the 0.01 level (2-tailed).

Berdasarkan tabel 5 diketahui bahwa nilai sig ( 2 tailed) adalah sebesar 0.000 yang berarti $\mathrm{p}<0.05$, sehingga hipotesis yang diajukan penulis diterima karena terdapat hubungan yang signifikan antara variabel berkendara selamat dengan Kecelakaan pengemudi transportasi roda dua online. Jika melihat seberapa besar hubungan antar variabel maka dapat dibandingkan pada tabel berikut ini:

Tabel 6. Tingkat Hubungan Berdasarkan Interval Korelasi

\begin{tabular}{ll}
\hline Interval Koefisien & Tingkat Hubungan \\
\hline $0,00-0,199$ & Sangat Rendah \\
\hline $0,20-0,399$ & Rendah \\
\hline $0,40-0,599$ & Sedang \\
\hline $0,60-0,799$ & Kuat \\
\hline $0,80-1,000$ & Sangat Kuat \\
\hline
\end{tabular}

Sumber: Sugiyono (2010:214)

Berdasarkan hasil output SPSS diketahui Correlation Coefficient adalah 0,428 dengan kata lain tingkat hubungan antara variable berkendara selamat dengan kecelakaan pengemudi transportasi roda dua online adalah pada kategori sedang.

\section{DISKUSI}


Berdasarkan hasil penelitian diketahui bahwa terdapat hubungan signifikan antara pengetahuan tentang berkendara selamat dengan kejadian kecelakaan pengemudi transportasi roda dua berbasis online di kota Pekanbaru dengan nilai koefisien korelasi sebesar 0.000 yang berarti $p<0.05$.

Hasil penelitian ini sejalan dengan teori bahwa pengetahuan berkendara selamat merupakan faktor penting dalam keselamatan berkendara. Menurut Ferry Efendi dan Makhfudli (2009) tindakan atau perilaku yang didasari oleh pengetahuan akan lebih diingat daripada tindakan atau perilaku yang tidak di dasari oleh pengetahuan.

Selain itu menurut Pamungkas (2014) pengetahuan berkendara selamat memiliki hubungan dengan kecelakaan kerja. Pengetahuan tentang berkendara selamat yang memadai meliputi pengetahuan tentang interaksi manusia, kendaraan dan lingkungan, mengembangkan keahlian mengemudi, akan mempengaruhi secara positif perilaku pengemudi. Ini akan menciptakan kebiasaan mengemudi yang lebih aman, yang akan menghasilkan penurunan jumlah kecelakaan.Sejalan dengan penelitian Wicaksono (2014) mengatakan bahwa perilaku pengemudi yang kurang antisipasi merupakan penyebab utama terjadinya kecelakaan lalu.

Penelitian ini juga sejalan dengan beberapa penelitian seperti Adzkia Andriani, (2017) bahwa terjadi peningkatan angka kecelakaan setiap tahunnya. Meningkatnya angka kecelakaan lalu lintas ini tidak sesuai dengan tujuan global Sustainable Development Goals untuk menurunkan 50\% angka kematian dan cidera akibat kecelakaan lalu lintas. Untuk mencapai tujuan tersebut maka perlu dilakukan penanganan faktor penyebab kecelakaan, perilaku pengendara salah satunya. Perilaku berkendara selamat berkaitan erat dengan tingkat kecelakaan lalu lintas.

Begitu juga degan penelitian Adzkia Andriani (2017) menujukkan bahwa $43 \%$ dari 21 pengendara ojek online $\mathrm{X}$ memiliki pengetahuan berkendara selamat yang masih di bawah rata-rata. Oleh sebab itu diperlukan sebuah program berkendara selamat untuk meningkatkan pengetahuan dan sikap aman berkendara. Hasil analisis bivariat menunjukkan terdapat perbedaan rata-rata nilai pengetahuan sebelum dan sesudah intervensi program berkendara selamat $(\mathrm{p}$ value $=0.000)$. Nilai rata-rata pengetahuan aman berkendara meningkat sebesar 11,2\%. Hasil analisis bivariat juga menunjukkan terdapat perbedaan rata-rata nilai sikap aman berkendara sebelum dan sesudah intervensi program berkendara selamat $(\mathrm{p}$ value $=0.000)$ atau dapat dikatakan bahwa pengaruh program berada pada $p$ value tinggi, sebab $p$ value $0.000<$ $\mathrm{P}$ value 0.05 . Nilai rata-rata sikap aman berkendara meningkat sebesar $12,6 \%$. Dengan adanya berkendara selamat diharapkan tingkat kecelakaan lalu lintas berkurang.

\section{KESIMPULAN}

Berdasarkan analisis data dapat disimpulkan bahwa terdapat hubungan signifikan antara pengetahuan berkendara selamat dengan kecelakaan pengemudi transportasi roda dua berbasis online. Saran untuk pengemudi transportasi roda dua berbasis yaitu agar para pengemudi online dapat menambah pengetahuan mengenai berkendara selamat dari berbagai sumber serta pelatihan, sehingga dapat mengurangi kecelakaan pengemudi bagi dirinya, penumpang dan pengemudi lain serta pengguna fasilitas jalan raya lainnya. 


\section{DAFTAR PUSTAKA}

Abojaradeh M., (2013). "Evaluation of Pedestrian Bridges and Pedestrian Safety in Jordan" Journal of Civil and Environment Research issued from IISTE USA. Volume 3, No. 1, 2013: 66-78.

Bagyono. (2004). Mengikuti Prosedur Kesehatan,Keselamatan dan Keamanan di Tempat Kerja. Pesona Wisata Klaten. Yogyakarta

ETSC (2011). 2010 Road Safety Target Outcome: 100,000 fewer deaths since 2001. 5th Road Safety PIN Report, European

Montazeri (2004)A. Road-traffic-related mortality in Iran: a descriptive study. Public Health.;118(2):110-3.

Manurung, Jeffry Rio. 2010. Hubungan Faktor-Faktor Penyebab Dan Akibat Kecelakaan Lalu Lintas Pada Pengendara Sepeda Moto

Astuti W (2012). Faktor-faktor yang mempengaruhi minat masyarakat dalam memilih angkutan tranJogja di Malioboro

Constance A (2016). Future Transport Technology. Transport For NW

EU-OSHA ( 2010). A review of accidents and injuries to road transport drivers, European.

Ismeik M., Jrew B., and Nithal A., (2010), Development of driver behavior accident prediction model. International Journal of Natural \& Engineering Science

Nantulya VM (2011). The neglected epidemic road traffic injuries in development.BMJ

Rachmawati, K. (2008). Manajemen Sumber Daya Manusia. ANDI. Yogyakarta

World Health Organization (2008). The Global Burden of Disease 2004 Geneva

World Health Organization(2015). Health in 2015 from millennium development goals to sustainable development goals. Geneva: Author 